\title{
KEY PERFORMANCE INDICATORS OF COMPATIBILITY PROCESS BETWEEN KNOWLEDGE WORKERS AND WORKPLACES
}

\author{
Laura Gaižauskiene் $\dot{1}^{1}$,̌ivilè Tunčikienè ${ }^{2}$ \\ Department of Management, Faculty of Business Administration, \\ Vilnius Gediminas Technical University, Saulètekio al. 11, Vilnius, Lithuania \\ E-mails: ${ }^{l}$ laura.gaizauskiene@vgtu.lt; ${ }^{2}$ zivile.tuncikiene@vgtu.lt (corresponding author)
}

Received 11 March 2020; accepted 07 May 2020

\begin{abstract}
The study in this article reveals the main structure of indicators that should be used in order to measure compatibility process in knowledge-intense organizations. Due to shift of management logic of Fit theory and extencively accepted presumption of talent shortage, management of compatibility became in highlight. Many research organizations and business sector companies are using key performance indicators for managing compatibility, but there is lack of data how successfully public sector companies are using them. Created and proposed methodology of assessment is a preparation step of empirical research. The systemic analysis of indicators which are used in managing compatibility between knowledge workers and workplaces solutions in a dynamic approach were investigated to create application technique.
\end{abstract}

Keywords: key performance indicators, knowledge workers, workplaces, Fit theory, dynamic compatibility process, knowledge-intense organization.

JEL Classification: M12, M54.

\section{Introduction}

Many organizations, which pay specific attention to the management of their people as the asset, understand that strategic competitiveness is achieved by aligning their human resource management (HRM) strategies with company's main strategy and policies. This strategic fit process is hardly achieved as an organisation is a dynamic entity performing in the chaotic environment and the fit has dynamic nature by itself (Boon et al., 2018).

Nevertheless, as the Fit theory is the basic assumption which validate the existence of the HRM per se with all its functions, the key performance indicator (KPI) system allows measuring the manageable processes. Taking wide and complex approach of the main purpose of the HRM, the compatibility of the employees and their workplaces is seen as the main purpose that consists of different dimensions and levels but integrates many aspects of the strategic management and organizational performance.

Depending on the fit type, strategy of human resource management is selected. The quest of compatibility between knowledge workers and workplaces is considered to be the principal assumption in the HRM, and the attention is paid individual work productivity manifested directly or via mediators (O`Boyle Jr. \& Aguines, 2012). However, the KPIs allow to understand how effec- tively the organization is managing its employed human capital (HC) by implementing the main strategy of HRM. This relationship is presented by many well-known scholars, e.g. Becker et al. (2001), Kaplan and Norton (2008) etc.

Although, there exist many methods and techniques to map the strategic situation of the organization, but some of them might be very complex and hardly used in practice. Others, like KPI system, analysed without explanations and open questions, may not reveal diverse aspects about phenomenon being studied, but due to its application clarity and relatively high impartiality, it may be one of the best way to track implementation of strategic objectives.

The research problem of KPIs in HRM could be divided into strategic, operative, and tactical levels (Syvajarni, 2016). The frequency of measuring can differ depending on the KPI and the meaning of it. It is also essential to be able to define which KPIs are paramount and which of them are just interesting metrics that also could be followed for operational reasons. One important aspect here is that KPIs should be defined by the top management of the company and those should have real strategic value. Instead of just presenting the situation of the past, decent KPI system should help to predict the future (Syvajarni, 2016; Gogoleva et al., 2017). 
Compatibility is seen as one of the most important aspects in the HRM as the fit between person and workplace theory is the fundamental precondition for the success of organization. The main principle that should be applied in looking for the factors along the process of compatibility is reciprocity or mutuality between workplace characteristics and knowledge employees competencies. It means that if the factor is important to one part to the equation knowledge worker - workplace, it should be significantly important to another part as well. This condition has two folded purpose: first, it makes the system of indicators dynamic and such way it better reflects the real-world situations; second, it allows to eliminate the factors from the list which creates information excess and unnecessary buzz. As the system encompasses many levels starting from individual and ending up at the strategic - application of KPIs system is one of possible analytical options.

Another important principle which should be applied is application of stratification levels. In other words, based on the company's resources and the will to allocate them to solve particular issues, the scale should be selected. Theoretical assumption implies that the more detailed management level is selected, the better outcomes should be. It is very likely to be true but operating in the realworld situations with scare resources, one should always made a decision of the precision level. It is particularly important in managing knowledge people, because on one hand it is assumed that they do not like to be under high control, but on the other hand, they need special attention and helping hand.

The specified KPI system adopted to knowledge-based organisation should help to track all above mentions aspects as well as create HRM analytics system in it.

\section{Fit theory and specificity in knowledge-based environment}

The concept of fit is very complex, multifarious and polisemantic (Edwards \& Billsberry, 2010). It is been proven and accepted for some time that fit has impact on employees work satisfaction, organisational loyalty, etc.

Fit theory was first formulated by the Parsons (1909) in his practically applied paperwork on vocational choice. The main idea was very trivial - a person should possess a specific set of skills and abilities if he wants to get a job and keep it. From that moment this simple presumption was developed in many levels: individual, group, organiza- tional, as well as in many scientific fields with different terms in use: personal economics (Lazear \& Oyer, 2007) - match, ergonomics - compatibility (Genaidy et al., 2007; Realyvásquez \& Maldonado-Macías, 2018), human resource management (Purcell \& Boxall, 2015) - alignment, compliance, environment psychology (Gifford et al., 2011) congruence.

Probably the best explanation of Fit theory is made by Muchinsky and Monakan (1987) who suggested to define the concept of fit by two approaches with subtypes (Figure 1).

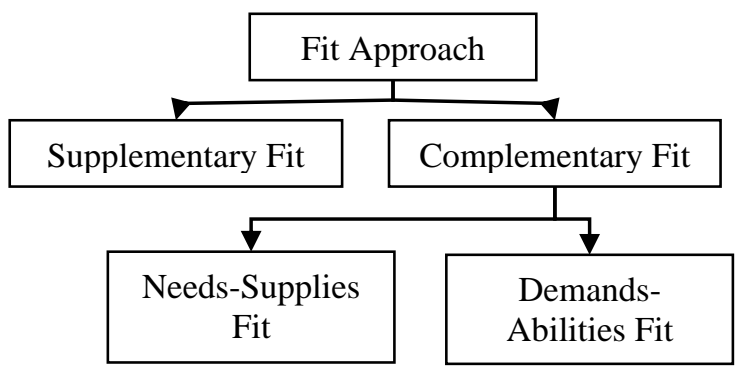

Figure 1. Typology of Fit (source: Muchinsky \& Monakan, 1987)

Supplementary fit is identified when characteristics of a person is homogenous with other individuals or group of people, which is environment. Such variables as individual satisfaction, performance results and tenure are used to measure fit. Complementary fit is identified when advantages of a person amend lacking work environment. To identify this type of fit, research is conducted by measuring variables of organizational level and is the main presumption for employee selection function. This type of fit has subtypes: (a) needs-supplies fit which is determined when organization fulfil person's needs and desires and (b) demands-abilities fit which is defined when a person possess abilities necessary to fulfil fit according to requirements stated by an organization (Kristof, 1996).

In the era of information technology spread and information circulation, different set of requirements are desired from the employee in the market. While creating knowledge societies, new industries and even new types of organisations called knowledge-based (KBO) (Pop \& Titu, 2018) and knowledge organizations (KO) (Hjørland, 2016), the knowledge workers have to be able work with information systems, huge data bases retrieving information and by applying creativity, analytical and critical skills, create knowledge based products or services. 
The characteristics of a $\mathrm{KBO}$, however, go beyond product to include process (organization's knowledge-based activities), purpose (mission and strategy) and perspective (worldview and culture that influence and constrain an organization's decisions and actions) (Hagiu \& Tanascovici, 2013).

Jääskeläinen and Laihonen (2013) argue that there are at least two ways how to measure KBO: (1) work productivity and well-being of the knowledge worker, (2) ability to create value for clients. Usually knowledge intensive organisations are understood as "people organizations" as their success depends on employees' qualifications and work effectiveness of individual experts. Despite the fact that many knowledge-intensive organizations are fairly small, performance measurement can support their management (Jääskeläinen \& Laihonen, 2013). Using KPI system in order identify the existing subsystems in such organizations, could be well applied technique.

\section{Classification of KPIs}

\subsection{Different levels of performance indicators}

Performance indicators are used not only to track the dynamic of processes in organisations and to manage them, but also to reveal trends in organized entity and predict future in VUCA environment (Dhir, 2019; Cousins, 2018).

At the fundamental level of KPIs, it is known two main groups: leading and lagging. According to Zhou and colleagues (2020), the lagging indicator represents the situation when one or more barrier fails simultaneously and resulting in a consequence. Lagging indicators are in general reactive and outcome based. The leading indicator represents the number and the size of holes in the barriers. A leading indicator can represent the performance of one barrier or more barriers at the same moment, depending on the description of the leading indicator. Leading indicators tend to be forward-looking and input based.

According to Badawy et al. (2016) there are four types of performance measures:

- Key result indicators (KRIs): it tells you how you have achieved in a perspective or critical success factor;

- Result indicators (RIs): tell you what you have done;

- Performance indicators (PIs): tell you what you must do;

- KPIs: tell you what to do to highly increase performance.
To describe the relationship between these four performance measures they authors uses an onion analogy (Figure 2).

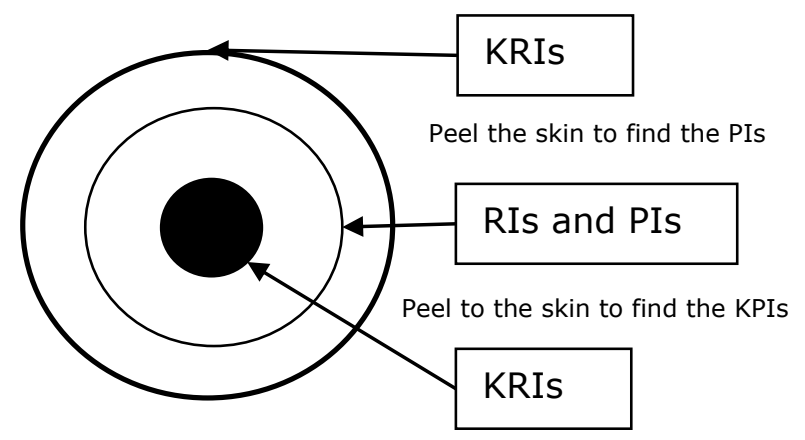

Figure 2. Four types of Performance Measurements (source: Badawy et al., 2016)

Parmenter (2015) has defined seven characteristics of effective KPIs:

- KPIs are non-financial measures therefore not expressed in any currency;

- usually KPIs are measured frequently, for example daily or weekly;

- CEO and the senior management team are in charge of defining the company's KPIs;

- an effective KPI is simple and understandable for the whole staff. Everyone must be able to understand what actions can be done to correct the KPIs direction;

- responsibility to do the required actions is team-based, so that a team or several teams together can work on those actions;

- KPIs do have a significant impact. Those affect on several of the organization's success factors and balanced scorecard perspective;

- effective KPIs have positive impact so that those encourage desired behaviour.

Most organizations have mismatching connection between the measures they are using and the results they are expecting. Due to lack of comprehensive knowledge, most organizations end up using the wrong measure in same measure as key performance indicators. KPIs should be a measure that explicitly guides the organization on what needs to be done in order to exponentially raise the performance of the firm. KPIs are implicitly concerned with the most strategic aspects to the organizational which are key to the present and the future of the organization (Parmenter, 2015). The key performance indicators of a firm are also referred to as key success indicators within management cycles. These measures help both the management and the personnel to understand and attain 
the organizational goals. KPIs have been used widely as measures of performance in modern organization to assess both the level of operational efficiency and productivity towards meeting the firm goals as well as the appraisal of the staff thus helping to motivate them leading to better productivity. In setting up key performance indicators for their staff the management incorporates the operational efficiency of the firm to ensure that as employees work towards attaining the goals set up for them, they will ultimately ensure better organizational performance. Essential to setting up key performance indicators is the ability of the management frameworks to align the needs of the organization with the objectives of the key performance indicators (Parmenter, 2015).

According to Bhatti et al. (2013) the performance indicators are defined as physical values that are used to measure, compare and manage the overall organizational performance and they usually include quality, financial, flexibility, delivery reliability, employees' satisfaction, customer satisfaction, safety, environment and community, learning and growth. The given explanation and list of KPIs is general. More specific and better adopted to reflect compatibility of knowledge worker and workplace fit would be performance indicators used in HRM.

In the following chapters there will be discussed the most used KPIs in the HRM specified for KBOs and their relations with the compatibility between knowledge workers and workplaces.

\subsection{Compensation KPIs and compatibility be- tween knowledge workers and workplaces}

Scholars have been and are still searching for clear empirical evidence that practices of HRM have significant impact on organizational performance. There are evidence that if high performance work system changes by one unit of standard deviation, the return on assets indicator increases $4,6 \%$ (Combs et al., 2006) or the market value changes from $10 \%$ to $20 \%$ (Becker \& Huselid, 2006).

Compensation of the human capital is the area where the biggest shift is still needed. According to Iazzolino et al. (2017) which idea is based on Drucker works $(1968,1999 a, 1999 b)$ argues that knowledge workers' productivity requires knowledge worker to be treated accordingly - as an asset rather than a cost - and the expenditure of training and other similar purposes should be interpreted as company's investment which would give return.

Renaud et al. (2015) have investigated the impact of compensation to workers retention and their research revealed that most of the reviewed studies show that compensation and training practices are positively associated with worker retention (Morin \& Renaud, 2009). The more motivated employees an organisation employs and the more management and compensation practices it implements, the higher its performance (Ferguson \& Reio, 2010). Both individual-based (e.g. marriage, gender, employee status) and firm-based factors (e.g. wages) had a significant impact on job retention (Huang et al., 2006) as well as revealing that HRM practices such as compensation and recognition had a higher effect on workers' intent to stay than on their commitment to the firm (Chew \& Chan, 2008).

Ramirez and Nembhard (2004) has collected and summarized twenty-one methods, which would help to measure the productivity of the knowledge workers. Moussa and colleagues (2017) had deconstructed the model of knowledge workers' productivity measurement by Oldham and Hackman (2010) and suggested to supplement it by factors which have significant impacts on motivation and more precisely reveals the conditions of working environment. The authors suggest to add three contextual dimensions, i.e., social, physical and organizational which reveals the principles presenting the assessment and reward of employee for his efforts, creativity, innovation, trust and workplace resources, career growth opportunities and administration of remuneration system that should be clear, transparent and adequate.

Table 1. The most used compensation KPIs in HRM (source: PVPA, 2019)

\begin{tabular}{|c|l|l|}
\hline No. & \multicolumn{1}{|c|}{ Compensation KPIs } & $\begin{array}{c}\text { Relation to } \\
\text { Compatibility }\end{array}$ \\
\hline 1 & Percentage of Cost of Workforce & Direct \\
\hline 2 & $\begin{array}{l}\text { Salary Competitiveness Ratio } \\
\text { (SCR) }\end{array}$ & Direct \\
\hline 3 & $\begin{array}{l}\text { Health Care Expense per Current } \\
\text { Employee }\end{array}$ & Direct \\
\hline 4 & Benefits Satisfaction & Direct \\
\hline 5 & Employee Productivity Rate & Direct \\
\hline 6 & Return on Investment (ROI) & Direct \\
\hline 7 & Cost per Hire & Direct \\
\hline
\end{tabular}

Meanwhile, investment into HC, i.e. education and training, increases work efficiency and quality. Although, organizations are facing increase of employee turnover and decrease of loyalty (Legkauskas \& Mazilauskaite, 2013). Due to 
this issue, organizations calculate their returns and choose to invest into those employees, which becomes the creators and implementors of their strategies. KPIs helps to perform this selection (Table 1) and is crucial to overall organizational performance (Medne \& Lapina, 2019).

\subsection{Employment KPIs and compatibility be- tween knowledge workers and workplaces}

It is logical that employment is determined partly because of turnover and turnover is consequence of compatibility between employees and workplaces. Indicator of turnover helps to evaluate and analyse fit between workers and workplaces (Boon et al., 2018). Nowadays work relations which are based on power balance between employees and employers, tendency of growing gig economy, short-term work relations and context of unpredictability, employers have constantly solved problem of turnover.

By using traditional management approach, turnover has impact on quality of organizational functional performance (Holtom et al., 2006; Holtom \& Inderrieden, 2006; Nyberg \& Ployhart, 2013), overall performance which could be evaluated by economical parameters (Hausknecht \& Trevor, 2011). There is a belief that employees as possessors and managers of the knowledge while starting to work for other company together takes away and an element of competitive advantage (Aime et al., 2010). However, there exist and different belief to such thinking when turnover has positive aspects. D. Somaya with her colleagues (2008) has empirically proved that the employee who has left the company creates the external social capital bond, which could be used to solve problems in HRM.

Generalized employment process can be divided into pre-hire period and post-hire period and use KPIs adopted accordingly (Table 2 and Table 3). Workforce is never a homogeneous and segmentation helps to achieve better understanding in the needs and expectations of each knowledge workers group.

Traditionally knowledge workers grouping is based on the work specification, although due to this the work and organizational environment should adjust in order to make them more productive, on individual bases these workers are the same people, which could be divided into groups by their age and gender.

In the scientific literature, there is opposite concept to turnover - retention. After it was understood that factors which encourage employees to stay differ from the ones which make them leave, these two concepts were used separately in researches (Cardy \& Lengnick-Hall, 2011; Holtom \& Inderrieden, 2006; Holtom et al., 2006; George, 2015).

Table 2. The most used employment KPIs of HRM in Pre-hire Period (source: PVPA, 2019)

\begin{tabular}{|c|l|l|l|}
\hline No. & \multicolumn{1}{|c|}{ Employment KPIs } & $\begin{array}{c}\text { Relation to } \\
\text { Compati- } \\
\text { bility }\end{array}$ & $\begin{array}{c}\text { Type of } \\
\text { KPI }\end{array}$ \\
\hline 1 & $\begin{array}{l}\text { Average Time to Find a } \\
\text { Hire/Fill Job Vacancy }\end{array}$ & Inverse & Objective \\
\hline 2 & $\begin{array}{l}\text { Candidates Interviewed } \\
\text { per Hire }\end{array}$ & Direct & Objective \\
\hline 3 & Yield Percentage & Direct & Objective \\
\hline 4 & Acceptance Rate & Direct & Objective \\
\hline 5 & $\begin{array}{l}\text { Hiring process Satis- } \\
\text { faction Rate }\end{array}$ & Direct & Subjective \\
\hline
\end{tabular}

Table 3. The most used employment KPIs of HRM in Post-hire Period (source: PVPA, 2019)

\begin{tabular}{|c|l|l|l|}
\hline No. & Employment KPIs & $\begin{array}{l}\text { Relation } \\
\text { to Com- } \\
\text { patibility }\end{array}$ & Type of KPI \\
\hline 1 & Absenteeism Rate & $\begin{array}{l}\text { Inverse } \\
\text { Mutual }\end{array}$ & Objective \\
\hline 2 & Average Tenure & Direct & Objective \\
\hline 3 & $\begin{array}{l}\text { Voluntary Termina- } \\
\text { tion Rate }\end{array}$ & Inverse & Objective \\
\hline 4 & $\begin{array}{l}\text { Involuntary Termina- } \\
\text { tion Rate }\end{array}$ & Inverse & Objective \\
\hline 5 & Retirement Rate & Direct & Objective \\
\hline 6 & $\begin{array}{l}\text { Average Age of } \\
\text { Retirement }\end{array}$ & $\begin{array}{l}\text { Direct } \\
\text { Mutual }\end{array}$ & Objective \\
\hline 7 & $\begin{array}{l}\text { New Hire 90-Day } \\
\text { Failure Rate }\end{array}$ & $\begin{array}{l}\text { Inverse } \\
\text { Mutual }\end{array}$ & Objective \\
\hline 8 & $\begin{array}{l}\text { First Year Voluntary } \\
\text { Termination Rate }\end{array}$ & $\begin{array}{l}\text { Inverse } \\
\text { Mutual }\end{array}$ & Objective \\
\hline 9 & $\begin{array}{l}\text { Training Cost per } \\
\text { Employee }\end{array}$ & $\begin{array}{l}\text { Direct } \\
\text { Mutual }\end{array}$ & Objective \\
\hline 10 & $\begin{array}{l}\text { Percentage of Em- } \\
\text { ployees Trained }\end{array}$ & $\begin{array}{l}\text { Direct } \\
\text { Mutual }\end{array}$ & Objective \\
\hline
\end{tabular}

Functions of HRM functions which are responsible for development of knowledge workers must search for innovative solutions in order to simplify identification of areas that are responsible for constant supply of talents and would increase organizational innovativeness and overall competitiveness. Therefore, in order to seize the opportunity to increase organizational innovativeness such area as employee selection must be exploit. It has been noticed that for this reason "assessment cen- 
tres", which helps to reveal teamwork abilities and innovativeness of future employees (Wiśniewska \& Wiśniewski, 2012). It is logical that HRM indicators must be oriented to determination of economy and effectiveness in high potential employees/talent selection.

\subsection{Culture KPIs and compatibility between knowledge workers and workplaces}

Research of work life quality also known as wellbeing of employees have reached such level that they have become as a mean to measure work environment factors. The research already has trends: first, working conditions, and second, work satisfaction (Gogoleva et al., 2017).

In the survey conducted by Siebert and Martin (2014) it is argued that in order to implement strategies of HRM, social context has significant impact to its success. Methods which are created to assess the quality between managers and workers relationship also are the ones used to capture compatibility elements. The famous scale called Leader-Member Exchange-Multidimensional (LMXMDM) created by Liden and Maslyn (1998). This scale aims to evaluate employees' perception about exchange between leader-member. There exists and modified scale named Supervisor LeaderMember Exchange-Multidimensional (SLMXMDM). This multidimensional model of social exchange is based on the presumption that leadermember social exchange phenomenon is much more complicated than total social exchange indicator, and it also consists of emotional, loyalty, cooperation, professional respect dimensions.

Culture dimension in organization is very important as Mahajan (2019) the culture of an organization represents the way things are done in the organization. It mainly revolves around the behavioural patterns and relationships. Culture is developed over time in the organization by the people who work for it. To create a dynamic culture, core values and its vision is a fundamental requirement. Organizations thus should focus on managing the talent: most skilled and experienced individuals. For organizations retaining talent is of ultimate importance to stay ahead of the competitors. Leaders outline the vision and mission for an organization - define and differentiate the organization. Leaders take the responsibility to model and reinforce the behaviour that helps to accomplish organizational goals and to ensure they are creating and cultivating a culture that promotes engagement of talent segment of the organization. In this way organizational cultures are created by leaders, what leaders pay consideration to, what actions are re- warded or punished, and distribution of resources is under consideration. Organizational culture is one of the determinants of effective talent management. The biggest challenge is to get senior leadership to believe that organisational culture is valuable asset and could be converted into KPI as any other important area for management (Mahajan, 2019) (Table 4). Bersin et al. (2015) mentions that companies with strong positive culture are most preferred companies by the employees. Positive culture driven companies put their employees first. Such companies work on the famous saying, "Take care of your people and they will take care of your customers". As per the survey conducted by Glassdoor in 2014, reveals top companies, chosen by employees for culture and values, as best places to work.

With the growth in economy, skills have become more specialized and competition for talent has increased. This has focused more attention on culture and talent management. It is also mentioned that every human resource program should address issues related to talent engagement and work culture, without a positive and meaningful work environment employee tend to look for jobs elsewhere (Bersin et al., 2015).

Table 4. The most used culture KPIs in HRM (source: PVPA, 2019)

\begin{tabular}{|c|l|l|l|}
\hline No. & \multicolumn{1}{|c|}{ Culture KPIs } & $\begin{array}{l}\text { Relation } \\
\text { to Com- } \\
\text { patibility }\end{array}$ & Type of KPI \\
\hline 1 & $\begin{array}{l}\text { Employee Satisfaction } \\
\text { Index }\end{array}$ & Direct & Subjective \\
\hline 2 & $\begin{array}{l}\text { Employee Happiness } \\
\text { Index }\end{array}$ & Direct & Subjective \\
\hline 3 & $\begin{array}{l}\text { Percentage of Em- } \\
\text { ployees Trained in } \\
\text { Company Culture }\end{array}$ & Direct & Objective \\
\hline 4 & $\begin{array}{l}\text { Percentage of Vaca- } \\
\text { tion Days Used }\end{array}$ & Direct & Objective \\
\hline 5 & Net Promotor Score & Direct & Subjective \\
\hline 6 & $\begin{array}{l}\text { Number of Full-Time } \\
\text { Employees }\end{array}$ & Direct & Objective \\
\hline 7 & $\begin{array}{l}\text { Number of Contrac- } \\
\text { tors }\end{array}$ & Inverse & Objective \\
\hline
\end{tabular}

Zhang and Liu (2006) argue that despite differences among main stakeholders, installing a partnering culture is crucial for improving overall project performance. Upon the findings from Malaysia, such partnering, ensuring the project success, should be based on the promotion of similari- 
ties in organizational cultures among partnering organizations.

According to PVPA researches, it is noteworthy that the process of employee selection is prone to lengthen. According to data from 30 days (2013) to 36 (2018). It indicates about the presumption that companies might have formulated more advanced requirements for team quality or high potential employees as well as they are using more sophisticated selection techniques which require more time.

Level of high potential employees is rising as in organizations which have talent management systems in 2016 percentage was 13.7, in 2017 - 14, in 2018 - 15.47 (PVPA, 2016, 2017, 2018). Hiring process satisfaction rate allows to identify effectiveness of the compatibility provisions between knowledge workers and workplaces and the quality of decisions.

\subsection{Calculation of compatibility index}

The calculations of compatibility index could be useful to create the benchmark instrument for companies in different sectors, capital origin, location, size, organization maturity. By the provided data, three main groups of KPIs compose compatibility (Figure 3 ). The problem in creating this index must answer the question of the weight of components.

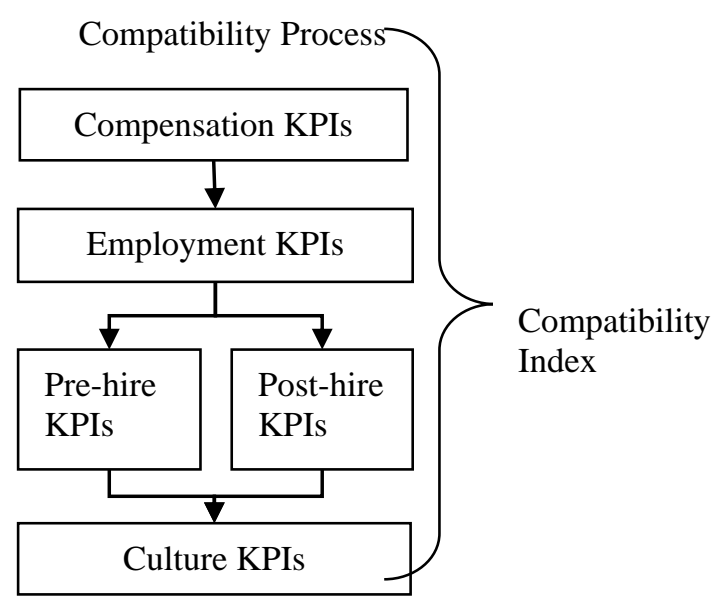

Figure 3. Compatibility index consists of components from compatibility process (source: compiled by authors)

\section{Conclusions}

There are several types of performance indicators, which measure processes in organisations. KPIs are the ones, which are the most paramount and extensively used in many organisations. According to conducted theoretical research they could be grouped and indicate the most important factors of compatibility - compensation, culture, pre-hire employment communication, post-hire employment policy.

Although there is always an opposing side of each phenomenon and it may appear that managing knowledge workers and their environment may no differ from industrial workers, but specific attention should be paid to KPIs that indicate constant training, engaging environment and innovating results.

\section{Acknowledgements}

Special thanks go to Lithuanian Association of Personal Management Professionals (PVPA) that agreed to share collected data of KPIs research.

\section{Disclosure statement}

Authors have no competing financial, professional, or personal interests from other parties.

\section{References}

Aime, F., Johnson, S., Ridge, J. W., \& Hill, A. D. (2010). The routine may be stable, but the advantage is not: Competitive implications of key employee mobility. Strategic Management Journal, 31(1), 75-87. https://doi.org/10.1002/smj.809

Badawy, M., Abd El-Aziz, A. A., Idress, A. M., Hefny, H., \& Hossa, S. (2016). A survey on exploring key performance indicators. Future Computing and Informatics Journal, 1(1-2), 47-52. https://doi.org/10.1016/j.fcij.2016.04.001

Becker, B. E., \& Huselid, M. A. (2006). Strategic human resources management: Where do we go from here? Journal of Management, 32(6), 898-925. https://doi.org/10.1177/0149206306293668

Becker, B. E., Huselid, M. A., \& Ulrich, D. (2001). The HR scorecard: linking people, strategy, and performance. Harvard Business Press, p. 235.

Bersin, J., Agarwal, D., Pelster, B., \& Schwartz, J. (Eds.). (2015). Global human capital trends 2015. Leading in the new world of work. Deloitte University Press, $112 \mathrm{p}$.

https://www2.deloitte.com/content/dam/Deloitte/a u/Documents/human-capital/deloitte-au-hc-globalhuman-capital-trends-2015-301115.pdf

Bhatti, M. I., Awan, H. M., \& Razaq, Z. (2013). The key performance indicators (KPIs) and their impact on overall organizational performance.

Boon, C., Eckardt, R., Lepak, D. P., \& Boselie, P. (2018). Integrating strategic human capital and strategic human resource management. The Inter- 
national Journal of Human Resource Management, 29(1), 34-67.

https://doi.org/10.1080/09585192.2017.1380063

Cardy, R. L., \& Lengnick-Hall, M. L. (2011). Will they stay or will they go? Exploring a customeroriented approach to employee retention, Journal of Business and Psychology, 26(2), 213-217. https://doi.org/10.1007/s10869-011-9223-8

Chew, J., \& Chan, C. C. A. (2008). Human resource practices, organizational commitment and intention to stay. International Journal of Manpower, 29(6), 503-522.

https://doi.org/10.1108/01437720810904194

Combs, J., Liu, Y., Hall, A., \& Ketchen, D. (2006). How much do high-performance work practices matter? A meta-analysis of their effects on organizational performance. Personnel Psychology, 59, 501-528 https://doi.org/10.1111/j.1744-6570.2006.00045.x

Cousins, B. (2018). Design thinking: Organizational learning in VUCA environments. Academy of Strategic Management Journal, 17(2), 45-56.

Dhir, S. (2019). The changing nature of work, leadership, and organizational culture in future ready organizations (CMC Senior Theses, 2064).

https://scholarship.claremont.edu/cmc_theses/2064

Edwards, J., \& Billsberry, J. (2010). Testing a multidimensional theory of person-environment fit. Journal of Managerial Issues, 22(4), 476-493.

Ferguson, K. L., \& Reio, T. G. (2010). Human resource management systems and firm performance. Journal of Management Development, 29(5), 471-494. https://doi.org/10.1108/02621711011039231

Genaidy, A., Karwowski, W., Salem, S., Jarrell, J., Paez, O., \& Tuncel, S. (2007). The work compatibility improvement framework: Defining and measuring the human-at-work system. Human Factors and Ergonomics in Manufacturing, 17(2), 163226. https://doi.org/10.1002/hfm.20071

George, C. (2015). Retaining professional workers: What makes them stay? Employee Relations, 37(1), 102-121. https://doi.org/10.1108/ER-10-2013-0151

Gifford, R., Steg, L., \& Reser, J. P. (2011). Environment psychology. In IAAP Handbook of applied psychology (Chapter 18, pp. 440-470). Black Publishing Ltd. https://doi.org/10.1002/9781444395150.ch18

Gogoleva, A. S., Sorokin, P. S., \& Efendiev, A. G. (2017). Problems and perspectives in research into the quality of work life in organisational studies. Society and Economy, 39(4), 597-616. https://doi.org/10.1556/204.2017.006

Hagiu, A., \& Tanascovici, M. (2013). Competitive intelligence in the knowledge-based organisation. Network Intelligence Studies, 1, 44-53.

Hausknecht, J. P., \& Trevor, C. O. (2011). Collective turnover at the group, unit, and organizational lev- els: Evidence, issues, and implications. Journal of Management, 37(1), 352-388. https://doi.org/10.1177/0149206310383910

Hjørland, B. (2016). Knowledge Organization (KO). Knowledge Organization, 43(6), 475-484. https://doi.org/10.5771/0943-7444-2016-6-475

Holtom, B., \& Inderrieden, E. (2006). Integrating the unfolding model and job embeddedness to better understand voluntary turnover. Journal of Managerial Issues, 18(4), 432-452.

Holtom, B., Mitchell, T., \& Lee, T. (2006). Increasing human and social capital by applying job embeddedness theory. Organizational Dynamics, 35(4), 316-331. https://doi.org/10.1016/j.orgdyn.2006.08.007

Huang, I. C., Lin, H. V., \& Chuang, C. H. (2006). Constructing factors related to worker retention. International Journal of Manpower, 27(5), 491-508. https://doi.org/10.1108/01437720610683976

Iazzolino, G., Laise, D., \& Gabriele, R. (2017). Knowledge-based strategies and sustainability: A framework and a case study application. Measuring Business Excellence, 21(2), 152-174. https://doi.org/10.1108/MBE-11-2015-0050

Jääskeläinen, A., \& Laihonen, H. (2013). Overcoming the specific performance measurement challenges of knowledge-intensive organizations. International Journal of Productivity and Performance Management, 62(4), 350-363. https://doi.org/10.1108/17410401311329607

Kaplan, R. S., \& Norton, D. P. (2008). The execution premium: Linking strategy to operations for competitive advantage. Harvard Business Press, p. 320.

Kristof, A. L. (1996). Person-organization fit: An integrative review of its conceptualizations, measurement, and implications. Personel Psychology, 49(1), 1-50.

https://doi.org/10.1111/j.1744-6570.1996.tb01790.x

Lazear, E. P., \& Oyer, P. (2007). Personnel economics (Working Paper 13480). National Bureau of Economic Research, 1-56. https://doi.org/10.3386/w13480

Legkauskas, V., \& Mazilauskaite, R. (2013). Psichosocialinių veiksnių ịtakos darbuotojų lojalumui tyrimas dirbančiųu Lietuvoje pavyzdžiu. Organizaciju vadyba: sisteminiai tyrimai, 65, 45-61.

https://doi.org/10.7220/MOSR.1392.1142.2013.65.4

Liden, R. C., \& Maslyn, J. M. (1998). Multidimensionality of leader-member exchange: An empirical assessment through scale development. Journal of Management, 24(1), 43-72. https://doi.org/10.1177/014920639802400105

Mahajan, A. (2019). Relationship of talent management with organizational culture: A discussion paper. The Indian Journal of Industrial Relations, 54(3), 471-481.

Medne, A., \& Lapina, I. (2019). The Key Performance Indicators (KPIs) and their impact on overall or- 
ganizational performance. Journal of Open Innovation: Technology, Market, and Complexity, 5(49), 1-14.

https://doi.org/10.3390/joitmc5030049

Morin, L., \& Renaud, S. (2009). La rétention des employés et les pratiques de formation et de rémunération: État des lieux de la littérature en GRH, psychologie et économie du travail. Actes de colloque, 20ème congrès de l'Association Internationale de Gestion des Ressources Humaines (AGRH), 1-17.

Moussa, M., Bright, M., \& Varua, M. E. (2017). Investigating knowledge workers' productivity using work design theory. International Journal of Productivity and Performance Management, 66(6), 822-834. https://doi.org/10.1108/IJPPM-08-2016-0161

Muchinsky, P. M., \& Monahan, C. J. (1987). What is person-environment congruence? Suplementary versus complementary models of fit. Journal of Vocational Behaviour, 31, 268-277. https://doi.org/10.1016/0001-8791(87)90043-1

Nyberg, A. J., \& Ployhart, R. E. (2013). Contextemergent turnover (CET) theory: A theory of collective turnover. The Academy of Management Review, 38(1), 109-131. https://doi.org/10.5465/amr.2011.0201

O'Boyle, Jr., E., \& Aguinis, H. (2012). The best and the rest: Revising the norm of normality of individual performance. Personnel Psychologu, 65, 79-119. https://doi.org/10.1111/j.1744-6570.2011.01239.x

Oldham, G. R., \& Hackman, J. R. (2010). Not what it was and not what it will be: The future of job design research. Journal of Organizational Behavior, 31(2-3), 463-479. https://doi.org/10.1002/job.678

Parmenter, D. (2015). Key performance indicators: Developing, implementing, and using winning KPIs. John Wiley \& Sons. https://doi.org/10.1002/9781119019855

Parsons, F. 1909. Choosing a vocation. Gay, London. $165 \mathrm{p}$.

Personalo valdymo profesionalų asociacija (PVPA). (2016). Personalo valdymo rodikliu tyrimas (Tyrimo ataskaita). 1-22.

Personalo valdymo profesionalu asociacija (PVPA). (2017). Personalo valdymo rodikliu tyrimas (Tyrimo ataskaita). 1-12.

Personalo valdymo profesionalų asociacija (PVPA). (2018). Personalo valdymo rodikliu tyrimas (Tyrimo ataskaita). 1-13.
Personalo valdymo profesionalų asociacija (PVPA). (2019). Personalo valdymo rodikliu tyrimas (Tyrimo ataskaita). 1-15.

Pop, A. B., \& Titu, A. M. (2018). Implementation of an integrated management system: Quality-information security in an industrial knowledge-based organization. QUALITY Access to Success, 19(166), 87-93.

Purcell, J., \& Boxall, P. (2015). Strategy and human resource management ( $4^{\text {th }}$ ed.). Palgrave, $368 \mathrm{p}$.

Ramirez, Y. W., \& Nembhard, D. A. (2004). Measuring knowledge worker productivity: A taxonomy. Journal of Intellectual Capital, 5(4), 602-628. https://doi.org/10.1108/14691930410567040

Realyvásquez, A., \& Maldonado-Macías, A. A. (2018). Measuring the complex construct of macroergonomic compatibility: A manufacturing system case study. Complexity, 1-10. https://doi.org/10.1155/2018/7374307

Renaud, S., Morin, L., Saulquin, J.-Y., \& Abraham, J. (2015). What are the best HRM practices for retaining experts? A longitudinal study in the Canadian information technology sector. International Journal of Manpower, 36(3), 416-432. https://doi.org/10.1108/IJM-03-2014-0078

Siebert, S., \& Martin, G. (2014). People management rationales and organizational effectiveness: The case of organizational trust repair. Journal of Organizational Effectiveness: People and Performance, 1(2), 177-190.

https://doi.org/10.1108/JOEPP-03-2014-0011

Somaya, D., Williamson, I. O., \& Lorinkova, N. (2008). Gone but not lost: The different performance impacts of employee mobility between cooperators versus competitors. Academy of Management Journal, 51(5), 936-953. https://doi.org/10.5465/amj.2008.34789660

Syvajarni, S. (2016). HR related KPIs that measure sustainainable efficiency and productivity in retail (Master's thesis). Helsinki Metropolia University of Applied Sciences.

Wiśniewska, S., \& Wiśniewski, K. (2012). Human resources management in a knowledge-based organization. Economics and Management, 17(4), 16201626. https://doi.org/10.5755/j01.em.17.4.3037

Zhou, Y. S., Zhang, M., Zhou, Y., \& Long, Z. (2020). Development and weight of leading and lagging KPIs for offshore structural integrity. Preprints. 